\title{
Streptococcus pneumoniae Serotype 23F IgG Antibody Measurement
}

National Cancer Institute

\section{Source}

National Cancer Institute. Streptococcus pneumoniae Serotype 23FIg G Antibody

Measurement. NCI Thesaurus. Code C142270.

The determination of the amount of Streptococcus pneumoniae serotype 23F IgG antibody present in a sample. 